\title{
Dzieci, zwierzęta i wielka zabawa. Przekształcenia wątków zwierzęcego folkloru w polskiej literaturze dla dzieci i młodzieży w perspektywie kulturowych studiów nad zwierzętami (cultural animal studies)
}

\author{
Children, animals and great fun. Modyfications of animal folklore \\ themes in Polish literature for children and young adults in \\ cultural animal studies perspective
}

\author{
|Ewelina Rąbkowska, \\ Uniwersytet Warszawski, \\ Muzeum Książki Dziecięcej w Warszawie
}

\begin{abstract}
One of the important elements of Professor Jerzy Cieślikowski's theory of great fun is a child-animal relation. Realistic situations of children's play with an animal according to Cieślikowski were sources of children's folklore and literature.

The author of paper proposes a new critical animal studies (CAS) for children's literature studies. This new perspective allows to put hypothesis about new child-animal relations in literature, new ecologic education values and - what is most important - lead us to new ethics, by overcoming taboo of animal's death and suffering in children's literature.
\end{abstract}

Key words: children's folklore, animal folklore, cultural animal studies, fun/play

Streszczenie: Jednym z bardzo ważnych elementów teorii wielkiej zabawy autorstwa Jerzego Cieślikowskiego jest opis relacji dziecko-zwierzę. Realne sytuacje zabawy dziecka ze zwierzęciem według Cieślikowskiego były istotnym źródłem dziecięcego folkloru, a co za tym idzie, literatury dziecięcej.

Autorka artykułu proponuje nową perspektywę badań literatury dziecięcej: critical animal studies (CAS). Spojrzenie to pozwala postawić hipotezy na temat specyficznych relacji dziecko-zwierzę w literaturze dziecięcej, nowych wartości edukacyjnych obejmujących ekologię, a także etykę, w których śmierć i cierpienie zwierząt zostałyby odtabuizowane.

Słowa kluczowe: folklor dziecięcy, folklor zwierzęcy, kulturowe studia nad zwierzętami, zabawa

\section{Od zabawy z dziećmi do literatury dziecięcej}

Johan Huizinga widzi zjawisko zabawy jako podwalinę i praźródło ludzkiej kultury (Huizinga 2011). Do ustaleń Huizingi odwołuje się polski badacz literatury dla dzieci i młodzieży Jerzy Cieślikowski, stwierdzając, że u źródeł kultury dziecięcej ${ }^{1}$ leży potrzeba bawienia się, i w tej kwestii

\footnotetext{
${ }^{1}$ Kulturę dziecięcą Cieślikowski określa mianem podkultury, definiując ją jednak jako „coś obok i innego od literatury”, a także „sytuacje bycia dzieci w ich folklorze”, byłby to zatem termin nadrzędny wobec folkloru dziecięcego (Cieślikowski 1975, 6). Folklor dziecięcy badacz definiuje następująco: „Folklorem nazywamy anonimową, często spontaniczną twórczość literacką lub literackopodobną. Twórczość słowną przede wszystkim, ale również gry i zabawy ruchowe czy manualne,
} 
między dorosłymi a dziećmi zachodzi podobieństwo (Cieślikowski 1985, 12). Badacz charakteryzuje zjawisko gier niedorosłych ludzi jako istotny element ich folkloru. Cieślikowski uznaje ten folklor za źródło literatury pisanej dla dzieci, co pozwala mu śledzić nie tyle historię, ile poetykę, analizować pewne popularne wątki literackie (Cieślikowski 1985, 5). Skupię się na tych aspektach powyższych badań, które mówią o tym, w jaki sposób zapisane $\mathrm{w}$ folklorze realne i kulturowe związki dzieci oraz zwierząt stały się źródłem najpierw specyficznego folkloru dziecięcego, a potem zasiliły literaturę dla dzieci i młodzieży. Przeanalizuję to zjawisko na przykładach konkretnych przedstawień i motywów zwierzęcych. Duża ich liczebność stanowi, moim zdaniem, odbicie tego, iż dziecku przypisywane jest szczególne zainteresowane innymi zwierzętami, że są one dla niego wyjątkowo atrakcyjne, nie tylko jako stały element jego otoczenia, dostarczając intensywnych bodźców poznawczych, ale jako istoty w pewien sposób bliskie jego umysłowości i wrażliwości².

Potrzeba bawienia się nie jest czymś zarezerwowanym wyłącznie dla człowieka. O gotowości do zabawy psów z dziećmi i dorosłymi ludźmi pisze Éric Baratay (Baratay 2014, 254). Cieślikowski zaznaczył z kolei, że jedną z najprostszych form folkloru dziecięcego, jaką jest kołysanka - jako ruch usypiania, któremu wtórnie towarzyszy dźwięk mruczenia lub tekst wywodzić można już z „«ludzkiej» czułości małpy, usypiającej swe potomstwo" (Cieślikowski 1985, 74). Literatura dziecięca utrwala wiele obrazów zabawy nie-ludzkich zwierząt i ludzkich dzieci, a także międzygatunkowe gry bez udziału człowieka ${ }^{3}$.

Cieślikowski rozpoczyna klasyfikację folkloru dziecięcego od podstawowych jego form, takich jak: gry, kołysanki, rymy i zabawy najprostsze.

które dorośli wymyślili dla dzieci, dla ich zabawienia, lub same dzieci powołały dla siebie. A tworzą dzieci folklor, obserwując i naśladując dorosłych, podsłuchując głosy przyrody, zwierząt i pojazdów mechanicznych" (Cieślikowski 1981, LI).

2 Historyk dzieciństwa, Philip Ariés, także porusza zagadnienie relacji między młodymi ludźmi a zwierzętami w zabawie, np. drewniany konik jako zabawa w naśladowanie prawdziwej konnej jazdy (Ariés 2010, 102). Badacz ten stawia jednak tezę, że nie wszystkie zabawy wynikały z naśladownictwa, ale były pierwotnie związane z religijną symboliką i miały charakter wspólnotowy, to znaczy połączone były z kalendarzem świąt i ich obchodzeniem. Wymienia tu przykład zabawki zwanej ptaszkiem na uwięzi. Historyk wywodzi tę zabawkę ze starożytnej Grecji, gdzie chłopcy w pierwszych dniach marca „strugali z drewna jaskółki kręcące się na osi i przystrojone kwiatami. Chodzili z nimi potem od domu do domu i zbierali podarki, ptak lub jego podobizna nie był więc zabawką, lecz elementem zbiorowego święta pewnej pory roku, w którym młodzież odgrywała przypisaną swemu wiekowi rolę" (Ariés 2010,103). Ariés przytacza przykłady ikonograficzne, na których dziecko ukazane jest z prawdziwym ptakiem przywiązanym sznurkiem za nogę, podczas gdy dziecko trzyma go w dłoni.

3 Zabawę antropomorfizowanych kotków „w ślepą babkę" zobrazowała Maria Konopnicka w książce Filuś, Miluś i Kizia (Konopnicka 1929, 17-19). Co ciekawe, koty bawią się tu na wzór dzieci, śpiewając zmodyfikowaną piosenkę do gry „ślepa babka”. Aktywności tej Cieślikowski poświęca specjalną uwagę, jako jednej z najstarszych, wyłącznie dziecięcych zabaw (Cieślikowski 1985, 31-35). Chociaż kocięta u Konopnickiej są - zdawałoby się - bawiącymi się dziećmi, autorka tak modyfikuje tekst towarzyszący grze, aby uwzględnić specyfikę gatunkową (skonwencjonalizowaną) tych zwierząt: „A ta ślepa babka, stara już nieboże, / Ani jednej myszki ułowić nie może!” (Konopnicka $1929,17)$. Interesujące są szczególnie te obrazy dziecięco-zwierzęcych zabaw, w których ujawnia się podmiotowość i sprawczość nie-ludzi. Zdolne są one narzucić reguły gry ludzkim dzieciom. Przykład takich „negocjacji” znaleźć możemy znowu u Konopnickiej w wierszu Prośba Filusia. Szczeniak przerywa zabawę z dzieckiem, kiedy ta staje się dlań uciążliwa, odzywa się przy tym ludzkim głosem we własnej obronie (Konopnicka 1988, 14). Inny ciekawy przykład odnajdziemy w opowiadaniu Emilii Waśniowskiej Kajtek (Waśniowska 1986). Tutaj także pies przerywa zabawę z dziewczynką, która ubrała go w strój niemowlęcy i wozi w wózku dziecięcym (jest to zatem zabawa „w dom” - z odgry- 
Najbardziej popularna kołysanka śpiewana w Polsce to „a - a - a - kotki dwa, szare, bure obydwa”. Ten refren powtarzany jest na różne sposoby: cicho, głośno, wolno, szybko, połączony z ruchem kołysania dziecka w ramionach (Cieślikowski 1985, 77). Fraza ta, rozbudowywana o zwrotki, stała się podstawą do tworzenia wielu wariantów. Inne zwierzęta związane ze snem dziecięcym to ptaki, szczególnie koguty. Cieślikowski wspomina także o tym, że nie-ludzie odgrywali rolę w tych tekstach folkloru dziecięcego, które łączyć można z fizjologią dziecka: z jego poczęciem np. silnie łączy się bocian, „przynoszący” dzieci, a z utratą zębów mlecznych - mysz, zabierająca zęby do norki (Cieślikowski 1985, 84-85). Obraz poszczególnych gatunków w tekstach dla dzieci jest często zatem po prostu literackim opracowaniem konwencji przyjętej w folklorze dziecięcym. Za punkt wyjścia słynnej serii opowiadań o dwóch kotach Sławomira Grabowskiego i Marka Nejmana pt. Przygody kota Filemona (Nejman, Grabowski 2013) możemy przyjąć wspomniany motyw kołysankowy. Konopnicka z kolei wyzyskuje konwencję folklorystyczną o bocianie, który „niesie” dzieci, w utworze Podróż na bocianie (Konopnicka 1988, 7).

Kiedy dziecko nie spało, czuwało, dorośli zabawiali je tworzonymi przez siebie rymami, zachęcającymi do gier manipulacyjnych, i w tych formach bardzo często pojawiały się motywy zwierzęce, by wymienić tylko: „Kosi, kosi łapki”, „Kizia, mizia”, „Ryba rak” czy „Idzie rak nieborak” albo „Tu sroczka”. Często aktywności te angażują palce małego człowieka i jego rodzica, odwołują się one bowiem do najprostszej symboliki, dostosowanej do rozwoju fizycznego i umysłowego dziecka. Okazuje się, że chociaż własne ciało jest pierwszym terenem eksperymentowania niedorosłych ludzi (Cieślikowski 1985, 96), na równi z nim doświadczają oni realnej obecności zwierząt: „Jest to symbolika najprostsza, sięgająca do przedmiotów wiejskiego otoczenia. Ruch dłoni ze zgiętymi palcami symbolizuje chód raka, głaskanie twarzy przypomina głaskanie futerka kota, stukanie palcem w otwartą dłoń - dziobanie kury" (Cieślikowski 1985, 96).

W miarę jak człowiek podrasta, zwiększa się zakres zabaw przygotowanych dla niego, poszerza się też repertuar zwierząt, które pojawiają się w tych zabawach. Niemowlę powiększając zasięg swej percepcji świata, rozpoznaje ich coraz więcej, stąd można już siedzącemu samodzielnie zaprezentować różne „Patataje”, łączące się z symboliką konia i podróży (Cieślikowski 1985, 103).

\section{Zapis cierpienia zwierząt w folklorze}

Cieślikowski zauważa, że elementem sporej części zabaw dziecięcych z motywem zwierzęcym jest „pantomima egzekucji” i sadyzm, wywodzą

waniem roli opiekuńczej, często obrazowana w książkach dla dzieci gra między dziećmi a zwierzętami; por. Hubben 2017). Kiedy dziecko wjeżdża z psem do lasu, ten nagle wyrywa się z wózka, czując trop dzika. Jednakże po krótkiej gonitwie za dzikiem jamnik wraca do dziewczynki, ale już nie chce podjąć zabawy „w dom” - wzbrania się przed wejściem do wózka. 
się one bowiem z dawnych obrzędów dręczenia zwierząt, np. cierpień im zadawanych. Dopiero takie zrytualizowane dręczenie mogło stać się obrzędem ofiarnym, który na dalszym etapie zdesakralizowany przekształcił się w zabawę ruchową, tekst zabawy - często pieśń (Cieślikowski 1985, 46-45).

Wiele gier dziecięcych ze schematem ruchowym ucieczki, pogoni, poszukiwania bierze swe nazwy od zwierząt: „w kotka i myszke”, ,w wilka i gąski”, często te aktywności są połączone z elementem kary pod postacią bicia - złapany zostaje uderzony. Gry „myśliwskie”, jak „w lisa”, także wiążą się z gonitwą, pochwyceniem, szukaniem (Cieślikowski 1985, 28). Zaskakuje fakt, że znowu w pamięci tych zabawowych pogoni zapisana jest przemoc odniesiona do świata zwierzęcego. Sytuacje agresji, napadu, zagrożenia, strachu inscenizowane były $\mathrm{w}$ wielu udramatyzowanych wariantach gry „w wilka i gęsi” („wilka i owce”, ,jastrzębia i kurczęta”) (Cieślikowski 1985, 35). Prześladowany przez ludzi i psy zając stał się bohaterem gier o genezie myśliwskiej „w zająca”. Cieślikowski pisze: „Sytuacje, w których znalazł się zając, kończyły się najczęściej tragicznie" (Cieślikowski 1985, 40). Bardzo podobna do gry „w zająca” była zabawa określana jako „Czarny baranie”. Baran próbował wydostać się z koła, które śpiewało piosenkę przypisaną do zespołu ruchowego, gdy mu się nie udało, rozpoczynał się pościg i lżenie go. Dziś ta zabawa jest już całkowicie zapomniana. I tu znowu genezę gry wywodzi się z praktyk okrucieństwa wobec zwierząt - egzekucji tych istot poprzedzonej szyderstwem i inwektywami wymierzonymi w nie.

Jeśli zatem przyjmiemy, że te partytury zabaw i gier zwierzęcych zdezintegrowane z zespołem ruchowym - stały się jako składowa folkloru dziecięcego źródłem literatury dla dzieci, to uprawniona wydaje się teza, że literackie modyfikacje wątków zwierzęcych mogą być pierwotnie naznaczone cierpieniem zwierzęcym. Ale już w niektórych wersjach tekstów folkloru dochodzi do stopniowego łagodzenia zbyt drastycznych obrazów dręczenia zwierząt. Natomiast w literaturze dziecięcej można zaobserwować dążność do zerwania z redukowaniem nie-ludzkich gatunków do odczuwanego przez nie cierpienia. Nie neguje się go, ale zwierzę zyskuje niejednokrotnie możliwość wyswobodzenia się z sytuacji dla siebie opresyjnej. Istota nie-ludzka staje się sprawcza w ten sposób, że wpływa na swoją własną sytuację. $\mathrm{W}$ tekstach literackich inspirowanych folklorem zwierzęcym obserwuję nie tylko możliwość przyjaźni ze zwierzęciem/przemocy wobec niego, ale konieczność wsłuchania się projektowanego odbiorcy w słowa zwierzęcia, empatii z nim i zmiany swego postępowania wobec niego. Gatunki zatem stają się podmiotami, a nie przedmiotami narracji. Za przykład niech posłuży wiersz Żuczek Marii Konopnickiej. Już w pierwszej strofie zwierzę zwraca się bezpośrednio do dziecka, opowiadając o sobie, zmienia zachowanie człowieka potencjalnie dla siebie szkodliwe:

Wyszedł żuczek na słoneczko

W zielonym płaszczyku. 
- Nie bierz-że mnie za skrzydełka,

Miły mój chłopczyku.

Nie bierz-że mnie za skrzydełka,

Bo mam płaszczyk nowy;

Szyły mi go dwa chrabąszcze,

A krajały sowy.

Za to im musiałem płacić

Po dwanaście groszy,

I jeszczem się zapożyczył

U tej pstrej kokoszy.

Jak uszyły, wykroiły,

Tak płaszczyk za krótki;

Jeszcze im musiałem dodać

Po kieliszku wódki.

(Konopnicka 1934, 55)

\section{Zabawa przy pracy - miejsce dzieci i zwierząt w hierarchii społecznej a folklor zwierzęcy}

Cieślikowski pisał o wielowymiarowej relacji dziecka i zwierzęcia w społeczności wiejskiej, która polegała na wspólnej pracy i zabawie. Badacz podkreśla, że już od piątego roku życia matka kazała swemu potomkowi „wyglądać na kury”. Czas trwania obowiązków stopniowo się wydłużał, aż do kilku godzin dziennie spędzanych na polu. W szóstym i siódmym roku zaczynało się „pasynie gęsi”:

Faktem jest, że dziecko wiejskie już od małego, praktycznie już od lat trzech, było wprowadzane w czynności gospodarskie. Domeną zajęć dzieci było pasanie (pasionka), porządek zhierarchizowany według wieku pasących, według zamożności ich rodziców i według tego, co się pasło i gdzie (Cieślikowski 1985, 84).

Pastuszkowie kóz i gęsi stali zatem najniżej w hierarchii, potem świniarczykowie, a dopiero podrostki mogły paść krowy i konie. Uszeregowanie pastuszków było, jak widzimy, ściśle związane z hierarchią zwierząt gospodarskich, w której najniżej stała koza.

Praca zarówno dzieci, jak i zwierząt jest zagadnieniem bardzo złożonym, a jej rola $\mathrm{w}$ rozwoju cywilizacji wciąż pozostaje niedoceniona. Zaproponowana przez Barataya formuła historii opowiedzianej z perspektywy zwierząt uświadamia $\mathrm{w}$ zasadzie to, że liczne procesy rozwojowe w obrębie cywilizacji bez pracy tych nie-ludzkich istot nie mogłyby zajść. Historyk wymienia tu rewolucję rolniczą, a potem przemysłu spożywczego, niemożliwą bez wielkoskalowej hodowli zwierząt, przebieg I wojny światowej, na który wpływ miała siła pociągowa nie-ludzi, która zresztą warunkuje także rewolucję przemysłową „wieku pary” (Baratay 2014). Od ponad stu lat jednak powstaje grupa gatunków niepracujących (do towarzystwa), a ciężka praca innych (np. w cyrku, zoo, laboratorium medycznym, 
w hodowli przemysłowej) coraz częściej spotyka się z ostrym sprzeciwem (Barcz 2014, 186-187).

Te same procesy wcześniej objęły dzieciństwo człowieka. Ariés potwierdza w zasadzie uwagi Cieślikowskiego na temat konieczności pracy niedorosłych ludzi, która właściwa była dla średniowiecza. Taki stan rzeczy utrzymywał się najdłużej na terenach wiejskich. Dziecko żyło w domu do siódmego roku życia (chociaż zajęte pracami gospodarskimi), aby potem zostać wysłane na służbę do obcych, uzyskiwało wtedy status „ucznia”. Był to zwyczaj bardzo powszechny w Zachodniej Europie. Faktem jednak jest, że niedorośli pracowali od najwcześniejszych lat, a kształcenie odbywało się drogą nauki zawodu, czyli pracy i służby (Ariés 2010, 271-276).

Nowoczesna formuła dzieciństwa jako czasu wolnego od pracy zarobkowej ukształtowała się „pomiędzy schyłkiem XIX wieku a początkiem I wojny światowej" (Kehily 2008, 16). Wartość dziecka przesunęła się obecnie z obszaru ekonomicznego do uczuciowego, a dorosły:

widzi dzieciństwo jako okres życia, w którym należy oddawać się zabawie i beztroskim przyjemnościom, kiedy dziecko chronione jest przed wpływem realiów świata pracy dorosłych, otoczone troską, trzymane w cieple i dobrze odżywione (Kehily 2008, 17).

Wyłączenie dziecka z grupy osób pracujących miało także niebagatelny wpływ na folklor dziecięcy. Związany z zabawą przy pracy dziecięcy folklor wiejski stopniowo ewoluował w stronę dziecięcego folkloru miejskiego. Ta nowa forma nie jest związana z obowiązkową pracą swego dziecięcego adresata, za to ujawnia się $\mathrm{w}$ niej związek $\mathrm{z}$ nauką i zabawą. $\mathrm{W}$ obydwu odmianach folkloru jednak obecność zwierząt jest istotna. Warto też wspomnieć, że „bezczynne” dziecko utorowało drogę „bezczynności” zwierząt do towarzystwa na łonie nowoczesnej rodziny, których wartość ekonomiczną zastąpiła wartość emocjonalna, tak jak to się stało w przypadku potomków rodziny.

Folklor dziecięcy dla najmłodszych w społeczności wiejskiej był tworzony przez dorosłych - jak wspominałam - po to, by je ukołysać lub zabawić. Starsze dzieci, wzrastając, stopniowo zdobywały samodzielność, poszerzały obszar swej aktywności. W momencie wkraczania w świat pracy, wchodziły według Cieślikowskiego w zupełnie nową "sytuację folklorotwórczą" (Cieślikowski 1975, 87), kiedy to same powoływały własne twory. Typowe sytuacje folklorotwórcze na wsi wiązały się z wypasem bydła, pławieniem koni, chodzeniem do lasu na grzyby, jagody, na jarmark, zatem miejscami związanymi z taką twórczością będą: las, łąka, rzeka, wiejska droga, kościół. Cechą charakterystyczną sytuacji folklorotwórczych jest gromadne przebywanie młodych ludzi bez nadzoru dorosłych. Z kolei dziecięcy folklor miejski, którego typowymi miejscami pozostają przedszkole, szkoła, podwórko, powstaje pod większym wpływem dorosłych, bo intensyfikuje się kontrola rodzicielska nad niedorosłymi w mieście (Cieślikowski 1975, 90). Dlatego w obydwu odmianach folkloru widać wymiar buntu dziecięcego: w folklorze 
wiejskim dzieci układają np. rymowanki parodystyczne względem dorosłych i oficjalnych obrzędów oraz zwyczajów (np. wesela), a w folklorze miejskim często dodatkowo dochodzi do głosu element przekory, nieposłuszeństwa względem opiekunów (np. użycie wulgaryzmów, obscenicznych skojarzeń).

Różnicę między tekstami literackimi, które czerpały z wiejskiego folkloru dziecięcego, a tekstami powstającymi już w przestrzeni miasta, dobrze obrazuje zestawienie wcześniej cytowanego wiersza Żuczek Marii Konopnickiej z cyklem Zoo Jana Brzechwy. W Żuczku wszystkie zwierzęta są zajęte jakąś pracą. Jest to oczywiście praca „ludzka”, ale moim zdaniem na antropomorfizację w tekstach inspirowanych folklorem wiejskim składa się właśnie tak pojmowana emancypacja zwierząt poprzez pracę zarobkową ${ }^{4}$. Z kolei w wierszach ze zbioru Brzechwy w stosunku do folkloru wiejskiego zmienia się repertuar opisywanych gatunków i sceneria miejskiego zoo, w którym zwierzęta nudzą się. Obrazowana jest tu zarówno zmiana statusu zwierząt i ich roli w przestrzeni metropolii, jak i modyfikacja projektowanego czytelnika - dziecka miejskiego, które pozostaje w roli oglądającego gatunki rzadkie, ale w „nienaturalnej” dla nich sytuacji. Być może stąd wynika zjadliwy humor wierszy, którego ostrze pozornie wymierzone jest przeciw zwierzętom w zoo, ale moim zdaniem to w istocie próba właściwej folklorowi dziecięcemu przekory na sytuację opresyjną i dzieci, i zwierząt. W sposób typowy dla tego folkloru wiersze drwią z postawy dorosłych (publiczności), którzy przetrzymują zwierzęta w zoo, np.:

\section{NIEDŹWIEDŹ \\ Proszę państwa oto miś. \\ Miś jest bardzo grzeczny dziś, \\ Chętnie Państwu łapę poda. \\ Nie chce podać? A to szkoda. \\ (Brzechwa 1973, 76) \\ TYGRYS \\ - Co słychać, panie tygrysie? \\ - A nic. Nudzi mi się. \\ - Czy chciałby pan wyjść zza tych krat? \\ - Pewnie. Przynajmniej bym pana zjadł. \\ (Brzechwa 1973, 83)}

Z zabiegiem unowocześniania związanych z folklorem wiejskim wątków zwierzęcych mamy do czynienia w tekście $W$ aeroplanie Juliana Tuwima, w którym typowa dorosła bohaterka folkloru: baba, babka, tu: babcia, wraz z kurą (tu: kurką) udają się we śnie w podróż aeroplanem. Wiersz zaczyna się, jakby był stylizacją folklorystyczną: „Miała babcia kurkę, kurkę złotopiórkę..." (Tuwim 1985, 3), a kończy oniryczną wizją połknięcia samolotu z kurką i babcią na pokładzie przez księżyc. Warto zwrócić uwagę na

${ }^{4}$ Warto zwrócić uwagę na przykład baśni opracowanej przez Grimmów pt. O czterech muzykantach z Bremy, gdzie właśnie emancypacja zwierząt ujmowana jest poprzez ich pracę - najpierw na rzecz człowieka. A potem, gdy nie-ludzcy pracownicy zestarzeją się, bez prawa do emerytury, wędrują do Bremy, żeby tam zająć się odpłatnym muzykowaniem (Grimm 1988, 55-58). 
przedstawioną w utworze wyjątkową więź, jaka łączy kobietę z konkretną przedstawicielką gatunku.

Ciekawy wątek skatologiczny w folklorze dzieci miejskich dotyka także tematów zwierzęcych obecnych w literaturze, np. wyliczanka podwórkowa:

Pimpuś Sadełko

nasr... w pudełko

dolał wody

krzyczy: „lody”! ${ }^{5}$

nawiązuje do utworu Szkolne przygody Pimpusia Sadełko Marii Konopnickiej (Konopnicka 1929). Mielibyśmy tu zatem do czynienia z wyjątkową sytuacją odwrócenia wcześniej omawianego procesu. Folklor dzieci miejskich wtórnie zasilany bywa przez literaturę dziecięcą. Być może przekorę wywołuje tu opresyjna przestrzeń szkoły, w której został umieszczony kot, zbyt naiwna dla współczesnego dziecka wizja kociego ucznia, „dosłowna” antropomorfizacja (ukazująca w efekcie pseudozwierzę - por. Pokora 2016, 189) i nachalne tendencje dydaktyczne utworu:

Nic milszego bowiem dziatki,

Jak kot pięknie wychowany,

Taki, jak go tu widzicie,

Nad miseczką od śmietany.

(Konopnicka 2011, 5)

\section{Realistyczne wizerunki/przedstawienia zwierząt $w$ folklorze dziecię- cym - zabawa i poznanie}

Cieślikowski pisze o „byciu” (Cieślikowski 1985, 122) zwierząt w folklorze dziecięcym. Owo „bycie” (obecność) jest ściśle związane i z głosem, jakie dana istota wydaje, i z tym, jaka ona jest. Zwierzęta zatem są poprzez to, co robią. Nie-ludzie w folklorze dziecięcym mają wymiar realny, ale ich realność jest przefiltrowana przez realność dziecka i społeczności, w jakiej ono żyje. Zwierzęta oczywiście są antropomorfizowane, ale wymiar ich bytowania biologicznego nie zaciera się w ramach specyficznej logiki folkloru. Logiczne tu jest to, że jeśli ptaki śpiewają, to śpiewają - jak dorośli na weselu (w unowocześnionej wersji ptasie odgłosy dziecko usłyszeć może w radiu, jak w wierszu Tuwima Ptasie radio). Jeśli śpiewają na weselu, to i tańcują, tak jak ludzie. Dalej zwierzęta mogą łączyć się w pary: sowa z wróblem, mucha z komarem, koza z wilkiem (Cieślikowski 1975, 123). Dziecko za pomocą zabawy poznaje zwierzęta, a antropomorfizacja okazuje się sposobem zbliżenia do nich, jak to nazywa Cieślikowski - „obłaskawiania”:

Ale to ich obłaskawianie nie jest nastawione na dorosłość (jak to ma miejsce w bajce zwierzęcej, w bajce Ezopowej), ale na dziecinność. Zwierzęta są w bajce jak dzieci. A ponieważ bajka jest tu ciągle otwarta na ekspresję: śpiewanie, tańczenie,

${ }^{5}$ http://forum.nostalgia.pl/viewtopic.php? $f=8 \& t=1009 \&$ start=15 (dostęp 21.02.2017). Dziękuję za zwrócenie uwagi na tę wyliczankę prof. dr. hab. Grzegorzowi Leszczyńskiemu. 
podskakiwanie - odbiorcy, czyli dzieci, stają się i wykonawcami utworu. Przybierają na siebie zachowanie, wygląd, naturę zwierzęcą. Dzieci są jak zwierzęta. Piosenka „Lata ptaszek po ulicy...” jest pantomimą latania, tańca i „bycia ptaszkiem” (...), próbowaniem zwierząt, ptaków za pomocą ich „języka”, ruchów, sposobów poruszania się. I to próbowanie jest naturalne dziecku - próba wejścia w pierze, w sierść, podlatywania, chodzenia na czterech łapach (Cieślikowski 1975, 124).

Jeśli dziecko zatem „naturalnie” dąży do poznania zwierząt w sobie właściwy sposób (naśladownictwa, antropomorfizacji ${ }^{6}$ ), to najbardziej doniosłe stają się te sytuacje w folklorze, kiedy to kontakt między zwierzęciem a dzieckiem zostaje zaburzony. Dzieje się to w trzech przypadkach.

Po pierwsze, jak wspomniałam, w folklorze tworzonym przez dorosłych dla niemowląt występuje wiele wątków straszenia dzieci zwierzętami po to, żeby te pierwsze uspokoić, zabawić, odwrócić uwagę od czynności dla dorosłego niepożądanej.

Po drugie, forma słowna niektórych gier ma genezę myśliwską czy związaną z rytualną egzekucją zwierzęcia, co może nie być już czytelne dla odbiorcy, mylnie sugerując "naturalną” redukcję zwierzęcia do sytuacji opresji. Zjawisko to okazuje się na tyle drastyczne, że ze względu na, jak sądzę, wrażliwość przypisywaną dzieciom powstają warianty o szczęśliwym zakończeniu (np. zajączek umknął psom lub myśliwym).

Po trzecie, przejście młodego człowieka do środowiska miejskiego, otoczenie go ścisłą opieką dorosłych, tak w szkole, jak i w domu, „udomowienie" dziecka, o którym pisałam, poskutkowało ograniczeniem jego kontaktów z naturą. Z konieczności relacje dziecko-natura musiały zmienić swój charakter na zubożone, podlegające kontroli, skrępowane władzą dorosłych. Wynikło to z realiów bytowania dziecka w przestrzeni miasta, gdzie łąka, wygon, las zmieniły się w podwórko, wiejska chata - w mieszkanie. W zabawie dziecięcej zatem i dziś obecność zwierząt jest istotna dlatego, że może stanowić próbę przywrócenia zerwanego kontaktu małego człowieka i istoty nie-ludzkiej.

Według poglądów Janusza Korczaka - zabawa dziecka nie może być lekceważona, jest bowiem formą poznania świata. Ono zamienia się w zwierzę, udaje je, naśladuje jego ruch i głos, a niektóre gry polegają także na zamianie w nie przedmiotu zabawy. I Korczak, i Cieślikowski analizowali jedną z najstarszych i najprostszych form gry zwierzęcej dziecka, jaką jest zabawa w konia. Nasycenie tej aktywności różnymi formami obecności konia jest dowodem na to, że gatunek ów „był kimś bardzo bliskim” (Cieślikowski 1975, 114) dziecku. Rzeczywisty koń, dostrzeżony bardzo wcześnie przez niedorosłego człowieka i zaliczony samodzielnie przez nie do klasy koni, trafia jako złożony twór do dziecięcej zabawy: już nazwa konia, krótki jednosylabowy wyraz, może tworzyć rymy, mające moc fabułotwórczą, można ten wyraz napisać na kartce albo narysować samego konia,

${ }^{6}$ E. Baratay pisze, że niepotrzebnie przekreślamy antropomorfizację jako sposób poznania, nie jest ona tymczasem pułapką poznawczą - przeciwnie niż antropocentryzm, czyli przekonanie o wyższości człowieka nad zwierzętami (Baratay 2014, 50). 
wreszcie można naśladować jego odgłosy klaskaniem języka, ruchem dłoni, nóg. Można także stać się koniem, naśladując go własnym ciałem. Często jednak w istotę tę zamieniał się zwykły kij, patyk, laska, przeistaczając się w specjalną zabawkę - model konia. Koń na biegunach i konie na karuzeli stanowią instrumenty tej samej zabawy (Cieślikowski 1975, 114-115).

W folklorze dzieci miejskich bezpośredni intensywny kontakt z koniem został przerwany lub ograniczony, ponieważ - „Współczesne dzieci jeżdżą samochodem" (Cieślikowski 1975, 116). Już Korczak pisał o dziecku w nowoczesnej rodzinie:

Zabawa jest nie tyle żywiołem dziecka, ile jedyną dziedziną, gdzie mu zezwalamy na inicjatywę w węższym lub szerszym zakresie. W zabawie dziecko czuje się do pewnego stopnia niezależnym. Wszystko inne jest przelotną łaską, chwilową koncesją, do zabawy dziecko ma prawo. Bawiąc się w konie (...), chwilowo ulega złudzeniu lub świadomie ucieka od szarzyzny życia. (...) Kijek nie jest dla dziecka koniem, ono $\mathrm{w}$ braku prawdziwego musi się pogodzić z drewnianym. (...) Które zamieni żywego psa na wypchanego, na kółkach? Które odda kuca za konia na biegunach? (Korczak 1984, 161-162).

Literatura dziecięca niejako próbuje przywracać tę zerwaną więź człowieka i konia, rozbudowując sugestywne wizje galopu ludzkiego dziecka na końskim grzbiecie. Wszystko przemawia za tym, że fabuły takie ocalają także utraconą podmiotowość, o której pisze Korczak - nie tylko dziecku, ale i przedstawicielom gatunku koni. Można tu wymienić chociażby utwory Mio, mój Mio oraz Bracia Lwie Serce Astrid Lindgren, tom cyklu narnijskiego Koń i jego chłopiec C.S. Lewisa ${ }^{7}$, a z polskich tekstów Wio! Leokadio Joanny Kulmowej.

\section{Zabawa ze zwierzęciem jako źródło empatii dziecka}

Korczak dostrzegł kompensacyjną rolę zwierząt w zabawie z dziećmi. Moim zdaniem dzieje się tak także $\mathrm{w}$ folklorze dziecięcym, a co za tym idzie, w literaturze dziecięcej. Niedorosły człowiek nie tylko poznaje nie-ludzi w zabawie, ale poznanie to buduje empatię w odniesieniu do nich, a także ma wymiar autopoznawczy dla bawiącego się dziecka. W tej koncepcji zabawy mały człowiek afirmuje naturę, świat, rzeczywistość (na Korczaka ogromny wpływ miały poglądy Nietzschego, por. Jaworek 2015). Cieślikowski pisał o tym później w ten sam sposób: „dziecko bawi się nie tylko kamykami, klockami, ale i myślami" (Cieślikowski 1985, 236), tworząc swoisty świat na opak, w którym myśl, słowo, rym rewolucjonizują „porządek świata" (Cieślikowski 1985, 236). W folklorze dziecięcym zostaje przywrócony dziecięcy i zwierzęcy raj, istoty nie-ludzkie zyskują moc osłaniającą tabu - przemocy, seksualności, dorośli muszą być częstokroć sparodiowani

Utwór ten analizuje Justyna Schollenberger w duchu kulturowych studiów nad zwierzętami, pisząc o sprawczości konia w jego relacji z jeźdźcem (Schollenberger 2016, 212-215). Taką intuicją wykazują się też wspomniane literackie fantazje zwierzęce dla dzieci. Koń i mały człowiek jednoczą się często we wspólnej sprawie, razem pokonują trudności, pomagają sobie, a jazda konna staje się czystą zabawą, symbolizując wolność. 
i ośmieszeni, i - co najważniejsze - strach przed zwierzęciem jest złagodzony (a nie tabuizowany). Przyjrzyjmy się po kolei tym przykładom kompensacyjnego działania zwierząt w folklorze dziecięcym.

Unieważniona zostaje hierarchia istot przyjęta przez dorosłych ludzi, a odnosząca się - jak napisałam - do wartości ekonomicznej każdej z nich. Koza, będąc w rzeczywistości najmniej wartościowym zwierzęciem gospodarskim, staje się bohaterką wielu rymowanek. Przedstawicielka tego gatunku zwykle jest w nich rogata, niesforna, spotyka ją kara lub śmierć, chociażby za zjedzenie babuleńce główek kapusty („Miała babuleńka...”, „Koza rogata”). Ale coś ciekawego zaczyna się dziać w warstwie znaczeniowej kolejnych wersji: pojawiają się postaci, które za kózką ujmują się, aż wreszcie w jednej z rymowanek koza umyka przed karą i grozi:

Ja, koza rogata, do pół boku obdarta,

Pobodzę rogami, przydepcę nogami,

Kto przyjdzie, to go zjem

(Cieślikowski 1985, 51)

Zwierzęta małe, nieistotne, niewartościowe, a wręcz odbierane jako odrażające - pluskwy, muchy, mole, ślimaki - są ulubionymi bohaterami folkloru:

Siedzi pluskwa na kominie

Mówi: - Świerszczu, weź ty mnie!

- A ty brzydka, garbata,

Idźże sobie do kata!

(Cieślikowski 1985, 131)

Folklor (w zgodzie ze swą logiką) niweluje różnice między zwierzętami i pozwala im żyć razem:

Sroka piwa naważyła w krążelowej dziurze,

A szczygiełek wodę nosił w czerwonym kapturze.

(Cieślikowski 1985, 128)

Jeśli zdarzają się kłótnie między zwierzętami, są one częścią konceptu zabawy. Często jednak dochodzi do nieoczekiwanych mariażów i zakochań:

Poszła mucha po wodę

do zimnego zdroju,

napotkał ją komar w drodze,

nie dał jej spokoju.

(Cieślikowski 1985, 124)

Obecność zwierząt neutralizuje także przemoc dorosłych wobec nich i wobec samych dzieci. Istoty takie jak: zając czy przepióreczka z gry myśliwskiej - zostają ocalone:

Siedzi zającek pod miedzą,

wilcaski o nim nie wiedzą,

a jak się dowiedzą,

Polonistyka. Innowacje

Numer 5, 2017 
to mu usy objedzą.

(...)

Idzie zając miedzą,

a psy i ludzie o nim nie wiedzą...

(Cieślikowski 1985, 40)

Częsta jest satyra na dorosłych stosujących przemoc wobec zwierząt, odwrócenie uwagi, zamiana ról.

A ty Janie Fabijanie,

pasiesz konie na wygonie.

Czym je pętasz?

Złotym pętem.

Czym poganiasz?

Złotym biczem.

Igi migi

idź spać za piec

do Jadwigi!

(Cieślikowski 1985, 205)

Zwierzęta folklorystyczne często psocą, psują, mają rozliczne wady, ale właśnie one stały się przedmiotem czułości: „Nic bowiem nie jest dziecku bliższe u zwierząt, jak ich wady (Cieślikowski 1985, 336).

Takie właśnie są zwierzęta w tekstach folklorystycznych: co prawda $\mathrm{z}$ brzemieniem cierpienia, ale bliskie dziecku, wzięte z jego bezpośredniej realności, emancypujące się przez pracę (choć pojętą na sposób ludzki). Teksty te mają moc ocalającą te istoty przed opresją, ujawnia się tu siła osłaniająca przez śmiech, wywrócenie porządku świata, niesubordynację, często również przez tendencje parodiujące.

Niedorosły człowiek, odrzucając wiedzę uznawaną za pożyteczną przez swego dorosłego opiekuna, pouczającą o „odrażającym”, „niebezpiecznym”, „strasznym” zwierzęciu, szuka czystej zabawy lub poznania niezafałszowanego pruderią czy lękiem dorosłych: „Karaluch, mysz, zdechły szczur (...) - mogą być ładne, gdy się je ogląda «czystym spojrzeniem», bez pruderii" (Cieślikowski 1985, 395-397).

Violetta Wróblewska w pracy Od potworów do znaków pustych. Ludowe demony $w$ polskiej literaturze dla dzieci potwierdza spostrzeżenie, że wiele spośród zwierząt obecnych w folklorze trafiło na karty literatury skierowanej do dziecięcego odbiorcy. Istoty - jak napisałam - pojawiające się w kontekście dawnych wierzeń, wzbudzające strach, którego kulturowy kontekst został dziś zapomniany, zracjonalizowały się, straciły sakralny wymiar, sprowadzone zostały niejednokrotnie do wymiaru komicznego, ich groza została zneutralizowana. Tę zmianę nazywa autorka właśnie modyfikacją od potworów do znaków pustych (Wróblewska 2014, 8).

Wróblewska analizuje transformację od ludowej grozy do dziecięcej czystej zabawy takich istot demonicznych i zwierząt, jak m.in.: strzyga, krasnolud czy smok. Ta sama jednak przemiana spotkała, moim zdaniem, 
wiele gatunków, które kiedyś - wyolbrzymione strachem człowieka - budziły grozę, ucieleśniały obawy towarzyszące codzienności i lęki pierwotne - na gruncie nowoczesnej literatury dla dzieci związane są z zabawą. Zwierzęta literackie mają także właściwości ochronne przed nieracjonalnym strachem, stanowią zarzewie buntu dziecka, które nie chce wierzyć w bajki dorosłych (Cieślikowski 1985, 397), odsyłają z powrotem do swej „zwykłości” (zatracając właściwą folklorowi cudowność lub fantastyczne wyolbrzymienie), do elementów realności ich bytowania, uruchamiając mechanizmy empatycznego utożsamienia się dziecka i zwierzęcia. Wymieńmy parę przykładów.

Niedźwiedź z dziecięcej gry ruchowej z nieodłącznym wierszykiem odsyłającym do sytuacji grozy, którego łagodniejsza wersja na gruncie folkloru nigdy nie powstała, jak to miało miejsce w przypadku rymowanek dotyczących innych gatunków zwierzęcych:

Stary niedźwiedź mocno śpi.

Cichutko chodzimy,

bo się go boimy.

Jak się zbudzi to nas zje.

(Cieślikowski 1975, s. 106)

Dopiero w literackiej modyfikacji, w wierszu Ludwika Jerzego Kerna Był sobie niedźwiedź, staje się niedźwiadkiem, niegroźnym, a wręcz potrzebującym pomocy w zaśnięciu:

Był sobie niedźwiedź daleko hen,

Co nie mógł zapaść w zimowy sen.

Inne niedźwiedzie już dawno spały,

Niektóre nawet głośno chrapały.

Chrapały chyba od miesiąca,

A on się w łóżku wiercił bez końca.

(Kern 1998, 6)

Trzeba niedźwiadkowi zaśpiewać kołysankę, a jeśli to nie pomoże, musi się on udać do sanatorium, gdzie otrzyma zastrzyk z przepięknymi snami. Więc $z$ jednej strony wiersz odsyła do realności zwierzęcia (snu zimowego), z drugiej zabawowy kontekst, jaki wywołuje sytuacja liryczna, rozwija się w zaskakujący sposób - nie ma tu miejsca na strach, za to objawia się duża przestrzeń do współczucia z niedźwiedziem, również poprzez antropomorfizację.

Równie znacząca jest modyfikacja obrazu istoty, o której pisałam, że stała najniżej w hierarchii zwierząt pasterskich: kozy. Niska pozycja tego gatunku w świecie ludzi nie może jednak wynikać tylko z jego nikłej wartości ekonomicznej, ale jest uwarunkowana kulturowo. Jak o tym wspomina Krystyna Heska-Kwaśniewicz, symbolika i mitologia kozy są szczególnie negatywne. Rozpowszechniano legendy, w których przybiera ona postać diabła. W Biblii z kolei funkcjonuje wyrażenie „kozioł ofiarny”, określające kogoś niesłusznie potępionego i oskarżonego. Przysłowia ludowe 
oraz znaczenia symboliczne przypisują kozie głupotę, upór i żarłoczność (Heska-Kwaśniewicz 1998, 32). Udowodniłam to, jak wizerunek kozy jest łagodzony już w różnych tekstach folkloru dziecięcego, ale najbardziej spektakularny akt „rehabilitacji” dokonał się w komiksowej opowieści Kornela Makuszyńskiego pt. 120 przygód Koziołka Matołka. Heska-Kwaśniewicz pisze, że pomimo swego imienia, nadal przywołującego na myśl pogardliwe skojarzenia $\mathrm{z}$ niedorozwojem umysłowym i fizycznym, koza w utworze Makuszyńskiego jest zwierzęciem mądrym, tolerancyjnym i empatycznym, w kolejnych przygodach ujawnia absurdalność zhierarchizowanego świata ludzkiego (Heska-Kwaśniewicz 1998, 37):

na wszystkich ilustracjach koziołek ma bardzo wyrazistą mimikę, zawsze widać na rysunku, czy jest wesoły, czy smutny, zdziwiony czy oburzony. Ma typową fizjonomię komiczną (...), ale na ogół cechuje się dobrym samopoczuciem i odpowiada mu każda życiowa rola i w każdej siebie akceptuje (Heska-Kwaśniewicz 1998, 30).

\section{Jak uczyć dziś o zwierzętach na materiale literackim inspirowanym folklorem?}

Z powyższych rozważań wynika, że zwierzęta są bardzo ważne w procesie wychowania dzieci. Przykłady zwierzęcego folkloru pokazują, że istoty te są odnotowane przez dziecko na wczesnym etapie jego rozwoju, stanowiąc naturalne otoczenie, dlatego w kulturach ludowych bywają treścią pierwszych rymowanych „lekcji” na temat przyrody i człowieka. Wszelkie gry oraz zabawy ruchowe z motywem zwierzęcym znajdują i dziś swe miejsce we wczesnej edukacji, jako że „przemiana” dziecka w zwierzę w zabawie jest naturalnym sposobem nauki na temat tych istot.

W miarę podrastania dziecko zyskuje coraz więcej wiedzy o świecie zwierząt i ludzi, ale może ona wtedy być już nacechowana spojrzeniem wartościującym. Mogliśmy zaobserwować, jak bardzo z jednej strony naznaczone jest ono cierpieniem, strachem, przesądem. $Z$ drugiej jednak strony mamy do czynienia z dowartościowaniem świata zwierząt wtedy, gdy tak silnie manifestują one swoje dążenie do niezależności - wszystkie istoty żywe (ludzie i zwierzęta) wydają się wtedy sobie bardzo bliskie: w pracy, w samostanowieniu, w używaniu własnej mowy. Dlatego tak ważne jest, aby stosunek empatyczny wobec zwierząt był wydobyty w procesie poznawczym. Nowoczesne kulturowe studia nad zwierzętami (cultural animal studies) w praktyce edukacyjnej postulują podejść w sposób krytyczny do wątków zwierzęcych obecnych w literaturze dla dzieci i młodzieży. Świadomość pochodzenia wielu $\mathrm{z}$ nich właśnie $\mathrm{z}$ folkloru oraz przekształceń, jakim ulegają obecnie, pozwala wydobyć walor empatyczny i poznawczy ich obecności w świecie rozwijającego się człowieka. Polonista ma prawo wybierać, analizować i posługiwać się takimi utworami, dzięki którym wrażliwość młodych ludzi wobec nie-ludzi zacznie się bez przeszkód kształtować. Zresztą proces narastania wrażliwości na zwierzęta w edukacji szkolnej 
już się rozpoczął. Głośno było niedawno na temat jednej z propozycji lektur szkolnych: Dziewczynka z szóstego księżyca Moony Witcher. Powieść ta, wypełniona wątkami bezsensownej przemocy wobec zwierząt, ukazująca ich cierpienie niemające żadnego uzasadnienia w treści, wzbudziła protesty uczniów i rodziców (Stangret 2015).

Krytyczne spojrzenie na tekst powinno stawiać pytanie o to, czy zwierzę jest podmiotem czy przedmiotem narracji, czy jego cierpienie nie jest tabuizowane, a praktyki wykorzystywania zwierząt nie są ukazane jako norma społeczna, czy wreszcie nie-ludzie nie są definiowani na zasadzie negatywnej opozycji do człowieka. W wielu kanonicznych tekstach z dzisiejszej perspektywy ujawnia się ambiwalencja: jedne gatunki, jako „użyteczne” dla człowieka, bywają dowartościowane (np. psy, konie, koty), wykorzystanie innych jako pokarm, do rozrywki jest uznawane za normę. Warto uczulać na przejawy gatunkowizmu - szowinizmu człowieka wobec innych zwierząt. Przeświadczenie, że tylko człowiek jako gatunek jest istotą racjonalną, samoświadomą, decyzyjną, zdolną do odczuwania bólu i przyjemności, a przez to jest „predysponowany” do instrumentalnego stosunku wobec pozostałych gatunków, jest obecne w naszej kulturze od wieków.

Do tekstów literackich skierowanych do dzieci, nawet tych z pozoru pisanych z perspektywy empatii, należy podchodzić indywidualnie i formułować pewne zastrzeżenia, jeśli chodzi o podjęty w nich temat zwierzęcy. W odniesieniu jednak do literatury inspirowanej folklorem zwierzęcym (czy to w odmianie wiejskiej, czy miejskiej), która modyfikuje motywy tego folkloru, należy sformułować wstępny wniosek - w świetle powyżej przedstawionej zaledwie wycinkowej analizy dostępnego materiału - że mogą być one materiałem pomocnym w literackiej edukacji poprzez zabawę, szczególnie młodszych dzieci. Wpisana jest w nie empatia, która warunkuje zmianę wrażliwości człowieka. Wynika to ze specyficznych, ogólniejszych procesów w rozwoju literatury dla dzieci, w których zwrot ku folklorowi miał niebagatelną rolę i może być związany - mówiąc ogólnie - z odejściem od „niewyrafinowanego dydaktyzmu” (Leszczyński 2013, 86). To właśnie tak wyraźna perspektywa czystej zabawy w folklorze sprawia, że osłabiane mogą być w inspirowanych nim tekstach i tendencje dydaktyczne, i kolonizatorskie w odniesieniu do podmiotu ludzkiego oraz zwierzęcego.

\section{Bibliografia:}

Ariés Philippe, 2010, Przyczynek do historii gier i zabaw, w: Historia dzieciństwa, Ochab M. (przeł.), Warszawa.

Baratay Éric, 2014, Zwierzęcy punkt widzenia. Inna wersja historii, Tarasewicz P. (przeł.), Gdańsk.

Barcz Anna, 2014, Zmierzch cyrku w Zwierzyńcu Antoniego Ferdynanda Ossendowskiego na tle rozkwitu kultury cyrkowej w XIX wieku, http://napis. edu.pl/pdf/Napis020_artykuly/NAPIS-2014_SERIA-XX_s182-196_Anna-Barcz.pdf 
Brzechwa Jan, 1973, ZOO, w: Brzechwa dzieciom, Szancer M. (il.), Warszawa.

Cieślikowski Jerzy, 1975, Literatura i podkultura dziecięca, Wrocław.

Cieślikowski Jerzy, 1985, Wielka zabawa, Wrocław.

Cieślikowski Jerzy, 1981, Wstęp, w: Antologia poezji dziecięcej, Cieślikowski J. (wybór i oprac.), Wrocław.

Grimm Wilhelm i Jacob, 1988, O czterech muzykantach z Bremy, w: Baśnie, Tarnowski M. (przeł.), Tuchanowska B., Majchrzak W. (il.), Warszawa.

Heska-Kwaśniewicz Krystyna, 1998, Zwycięstwo Koziołka-Matołka nad stalinizmem, w: Książka dla dziecka wczoraj - dziś - jutro, Heska-Kwaśniewicz K., Socha J. (red.), Katowice.

Huizinga Johan, 2011, Homo ludens. Zabawa jako źródło kultury, Warszawa.

Hubben Kelly, 2017, Mr. Dog Is a Conservative: Representations of Children and/ as Animals in Little Golden Books, w: Childhood and Pethood in Literature and Culture. New Perspectives in Childhood Studies and Animal Studies, ed. Anna Feuerstein, Carmen Nolte-Odhiambo, Routledge.

Jaworek Marta, 2015, Mit dziecka. Korczak - Nietzsche - Zaratustra, Warszawa.

Kehily Mary Jane, 2008, Zrozumieć dzieciństwo: wprowadzenie w kluczowe tematy i zagadnienia, w: Wprowadzenie do badań nad dzieciństwem, Kościelniak M. (przeł.), Kehily M.J. (red.), Kraków.

Kern Ludwik Jerzy, 1998, Był sobie niedźwiedź, w: Wiersze dla dzieci, Person S. (il.), Poznań.

Konopnicka Maria, 1929, Filuś, Miluś i Kizia. Nasze kotki, Nowakowski B. (il.), Warszawa.

Konopnicka Maria, 1934, Żuczek, w: Poezje dla dzieci, Warszawa.

Konopnicka Maria, 1988, Prośba Filusia; Podróż na bocianie, w: Stary zegar od pradziada, Poreyko M. (il.), Warszawa.

Konopnicka Maria, 2011, Szkolne przygody Pimpusia Sadełko, Bauer A.M. (il.), Warszawa.

Korczak Janusz, 1984, Jak kochać dziecko, w: Janusz Korczak. Pisma wybrane, t. I, Lewin A. (wprow. i wybór), Warszawa.

Leszczyński Grzegorz, 2013, Dialektyka ról czytelniczych w prozie Korczaka, w: Janusz Korczak. Pisarz, Czernow A.M. (red.), Warszawa.

Nejman Marek, Grabowski Sławomir, 2013, Przygody kota Filemona, Karwowska-Wnuczak J. (il.), Warszawa.

Pokora Patrycja, 2016, Człowiek mówiący psim głosem. „Psie życie” Józefa Wilkonia $w$ świetle studiów nad zwierzętami, w: Czytanie menażerii. Zwierzęta $w$ literaturze dziecięcej, młodzieżowej i fantastycznej, Mik A., Pokora P., Skowera M. (red.), Warszawa.

Schollenberger Justyna, 2014, Literackie ożywienie bestii - intertekstualne wątki bestiariuszy w "Harrym Potterze”, w: „Harry Potter”. Fenomen społeczny, zjawisko literackie, ikona popkultury, Kostecka W., Skowera M. (red.), Warszawa. 
Schollenberger Justyna, 2016, Gadajace konie. Zwierzęcy bohaterowie $w$ „Czasie wojny” Michaela Morpurgo oraz „Koniu i jego chłopcu” C.S. Lewisa, w: Czytanie menażerii. Zwierzęta w literaturze dziecięcej, młodzieżowej i fantastycznej, Mik A., Pokora P., Skowera M. (red.), Warszawa.

Stangret Michał, 2015, Otwórz klatkę i zaduś wiewiórkę. Opis bestialskiego traktowania zwierzat w lekturze, http://metrocafe.pl/metrocafe/1,145523,18 993212,otworz-klatke-i-zadus-wiewiorke-opis-bestialskiego-traktowania.html (dostęp 10.10.2016 r.)

Wróblewska Violetta, 2014, Od potworów do znaków pustych. Ludowe demony $w$ polskiej literaturze dla dzieci, Toruń.

Tuwim Julian, 1981, Pan Maluśkiewicz i wieloryb, Pokora M. (il.), Warszawa.

Tuwim Julian, 1985, $W$ aeroplanie, Tokarczyk M. (il.), Warszawa.

Waśniowska Emilia, 1986, Kajtek, Orłowska-Gabryś M. (il.), Warszawa.

\section{O Autorce:}

Ewelina Rąbkowska - literaturoznawczyni specjalizująca się w literaturze dziecięcej i młodzieżowej. Ukończyła Wydział Polonistyki Uniwersytetu Warszawskiego, a także studia podyplomowe „Literatura i książka dla dzieci i młodzieży wobec wyzwań nowoczesności” pod kier. prof. dr. hab. Grzegorza Leszczyńskiego. Uczestniczka studiów doktoranckich w Zakładzie Literatury Popularnej, Dziecięcej i Młodzieżowej ILP UW. Pracuje w Muzeum Książki Dziecięcej w Warszawie. Autorka artykułów naukowych, recenzji książkowych oraz monografii naukowej Potrzeba poczatku. Kategoria dzieciństwa $w$ polskiej współczesnej prozie wspomnieniowej (1987-2014), członkini PS IBBY oraz Pracowni Badań nad Literaturą dla Dzieci i Młodzieży. 
